\title{
Small mammal community structure and microhabitat use in the austral boundary of the Atlantic Forest, Brazil
}

\author{
Daniela O. de Lima1; Bethânia O. Azambuja²; Vagner L. Camilotti² \& Nilton C. Cáceres³
}

1 Programa de Pós-graduação em Ecologia, Universidade Federal do Rio de Janeiro. Ilha do Fundão, Caixa Postal 68020,
$21941-590$ Rio de Janeiro, Rio de Janeiro, Brasil. E-mail: daniela.ol.lima@gmail.com
2 Programa de Pós-graduação em Ecologia, Universidade Federal do Rio Grande do Sul. Avenida Bento Gonçalves 9500,
Campus do Vale, 91501-970 Porto Alegre, Rio Grande do Sul, Brasil.
${ }^{3}$ Departamento de Biologia, Universidade Federal de Santa Maria. Camobi, 97110-970 Santa Maria, Rio Grande do Sul, Brasil.

ABSTRACT. We investigated the richness, composition, and species relative abundance of a terrestrial small mammal community in a Deciduous Forest area in the austral boundary of the Atlantic Forest. The microhabitat use of the most common species was also investigated. Six rodents - Akodon montensis (Thomas, 1913), Oligoryzomys nigripes (Olfers, 1818), Sooretamys angouya (Thomas, 1913), Thaptomys nigrita (Lichtenstein, 1829), Mus musculus (Linnaeus, 1758) and Juliomys sp. - and one marsupial - Didelphis albiventris (Lund, 1840) - were captured. Thaptomys nigrita is recorded in the state of Rio Grande do Sul for the first time. Species richness was poor when compared with communities in the central portions of the Atlantic Forest, but equivalent to that found in the Araucaria and Dense Ombrophilous forests of southern Brazil. The species most often captured in our study, A. montensis and O. nigripes, are also the most common in the majority of faunistic studies carried out in the Atlantic Forest. Akodon montensis and S. angouya used places with high abundance of bamboo, possibly to avoid predators. Oligorizomys nigripes used areas with a high density of scrubs, what could facilitate aboveground movements, and was negatively correlated to mature forest indicators, which reinforce the idea that this species has opportunistic habits.

KEY WORDS. Akodon montensis; Decidual Forest; Oligoryzomys nigripes; Sooretamys angouya.

The Atlantic Forest, one of the most threatened biomes in the world, has a high mammalian diversity and endemism (Myers et al. 2000). Even though remnants of the Atlantic Forest span from the state of Rio Grande do Norte, northeastern Brazil, to as far South as southern Rio Grande do Sul (Collins 1990), most faunistic studies have been carried out in the central portion of the biome, southeastern Brazil, (e.g., Bonvicino et al. 2002, Geise et al. 2004, PARDini 2004, UMeTsu et al. 2006, PÜtTKER et al. 2008). Information on the austral regions of the forest is still scarce. The majority of studies that deal with the mammalian fauna of the southern portions of the Atlantic Forest are faunal surveys (CADEMARTORI et al. 2002, CÁCERES 2004, Cherem 2005, Scheibler \& Christoff 2007). In addition, there are few studies on the demographic patterns of small mammals inhabiting the Dense Ombrophilous Forest (Graipel et al. 2006, ANTUNEs et al. 2009) and studies on the abundance patterns (CAdemartori et al. 2004) and microhabitat selection (Dalmagro \& VIeIRA 2005) of mammals dispersed in the Araucaria Forest.

Most studies carried out in the austral Atlantic Forest have recorded four to 10 species of small mammals (CADEMARTORI et al. 2002, CÁceres 2004, Cherem 2005, Dalmagro \& Vieira 2005). In an austral Deciduous Atlantic Forest region, Scheibler \&
CHRISTOFF (2007) found an unexpectedly high species richness (15 species) particularly in abandoned agricultural fields (locally named capoeira), while in forest fragments only four species were recorded. By contrast, the central portions of the Atlantic Forest harbor up to 20 small mammal species per locality (Bergallo 1994, Bonvicino et al. 2002, Pardini \& UMetsu 2006, UMETSU et al. 2006).

In addition to species richness, information on species composition and relative species abundance are the most basic and important data to gather on small mammal communities. Most areas of the Atlantic Forest have a few generalist species that are common and easy to capture, and a large number of species that are rare and difficult to capture (e.g. Bonvicino et al. 2002, Dalmagro \& Vieira 2005, Pardini \& Umetsu 2006, SCheibler \& Christoff 2007). This pattern is responsible for a sampling bias that results in generalist species being recorded from almost anywhere, whereas the recorded distribution of rarer species has many gaps.

Another important ecological approach to the study of a small mammal community is the investigation of microhabitat use, a key factor in their structure (SCHOENER 1974). Studies on small mammals in many regions over the world have con- 
sidered microhabitat use crucial in niche segregation (DUESER \& Shugart 1978, Yahner 1982, SEAgle 1985, Fa et al. 1992, Brannon 2000). In an area of Dense Ombrophilous Forest, PÜtTKER et al. (2008) indicated the importance of micro-scale variation in the vegetation structure for the distribution of small mammal species in secondary forest fragments. In the Araucaria Forest, Dalmagro \& Vieira (2005) also found significant effects of microhabitat variables on species occurrence.

In this study we investigated the richness, species composition and abundance of a terrestrial small mammal community in a Deciduous Forest located in the austral boundary of the Atlantic Forest domain, and the microhabitat use of the most common species. We focused on two main questions. (1) Are the parameters richness, species composition and species relative abundance in this community similar to those found in other communities in the Atlantic Forest? (2) Are microhabitat characteristics correlated with the occurrence of small mammal species?

\section{MATERIAL AND METHODS}

The austral Atlantic Forest consists of four main formations: the Dense Ombrophilous Forest; the Mixed Ombrophilous forest (also known as Araucaria Forest), dominated by Araucaria angustifolia (Bertol.) Kuntze pines (Araucariaceae); the Coastal Forest on marine sandy soils (Restinga Forest) and the Deciduous Forest. These forest formations bound grassland vegetation with scattered forest patches known as Campos Sulinos (Quadros \& Pillar 2002).

This study was carried out in a fragment of Deciduous Forest (about 400 ha) connected to others forest areas and composed by primary and secondary forests. The study area is called Morro do Elefante by the local people. It is located $2 \mathrm{~km}$ away from an urban area and is used by the local population for trekking. This forest fragment is located on the hillside of the Serra Geral hills, municipality of Santa Maria, state of Rio Grande do Sul, Brazil (29 $40^{\prime} \mathrm{S}, 53^{\circ} 43^{\prime} \mathrm{W}$, Fig. 1). These hills are covered by one of the southernmost parts of the Atlantic Forest. At the base of these hills the forest is replaced by the Campos Sulinos grasslands. According to Machado \& LONGHI (1989), the arboreal vegetation of the study area is composed mainly by Leguminosae, Lauraceae, Myrtaceae and Meliaceae species.

The local climate is markedly seasonal, Cfa type, humid and subtropical, according to the Köppen classification (MORENO 1961). The mean annual temperature is $19.9^{\circ} \mathrm{C}$ and the annual rainfall averages $1520 \mathrm{~mm}$ (Departamento de Fitotecnia; Universidade Federal de Santa Maria), according to data from a Climatic Station located at $138 \mathrm{~m}$ a.s.l. and $4 \mathrm{~km}$ from the study area. Monthly average temperatures vary between $25.9^{\circ} \mathrm{C}$ in January to $14.1^{\circ} \mathrm{C}$ in July, and the annual rainfall is well distributed throughout the year.

Two trapping grids (1.35 ha each) were established inside the forest at 260 and $460 \mathrm{~m}$ above sea level. Each grid was sampled four times (March, May, July and October 2005) dur- ing seven consecutive nights each month. Inside each grid 30 pitfall traps and 40 wire-mesh live traps were placed. For pitfalls traps, 20 buckets of 20 liters and 10 buckets of 30 liters were used. The pitfalls were set up with plastic drift fences of 6 m length, disposed as a simple line with the bucket in the center. The wire-mesh live traps, of different sizes $(12 \times 12 \times 34$, $12 \times 11.5 \times 24,16.5 \times 16.5 \times 44 \mathrm{~cm})$, were placed on the ground. The traps in each grid were arranged on seven transect lines four transect lines with live traps interspersed by three transect lines with pitfalls. Each transect, with pitfalls or live traps, had 10 traps spaced out $10 \mathrm{~m}$ from each other. Traps with different sizes were disposed randomly. The distance between the transect lines was $25 \mathrm{~m}$. Traps were alternately baited with bacon or pumpkin with sardine. The use of pitfalls makes possible to record species that are rarely captured with standard trapping, such as some fossorial small mammal species. The combination of the two methods is currently considered one of the best sampling approaches for studies of small mammal communities (Williams \& Braun 1983, Lyra-Jorge \& Pivello 2001, Umetsu et al. 2006).

Undetermined individuals were collected and sent to specialists for karyotypic analyses and skull and skin comparisons. Individuals that could be identified in the field were measured, marked and released in the same capture station. Voucher specimens were deposited in the Fundação Zoobotânica do Rio Grande do Sul science museum (numbers 3085 to 3188), Porto Alegre, Rio Grande do Sul, Brazil.

To investigate microhabitat use, 14 variables were measured at each trapping station. These variables were chosen to gauge forest age and conservation status, forest structure and regeneration ratio and availability of nesting and hiding sites. The variables measured were the following: average canopy height above trapping station (visually estimated by comparison with an object of known height); canopy cover above trapping station (measured with a small mirror divided in 37 squares of $1 \mathrm{~cm}^{2}$ placed at $1.5 \mathrm{~m}$ height); number of trees between 10 and $20 \mathrm{~cm}$ of perimeter at breast height $(\mathrm{PBH})$ in a $3 \mathrm{~m}$ radius from the center of the trapping station; number of trees between 20 and $30 \mathrm{~cm}, 30$ and $50 \mathrm{~cm}$ and larger than $50 \mathrm{~cm}$ of $\mathrm{PBH}$ in a $3 \mathrm{~m}$ radius of the trapping station; number of scrubs in a transect of $6 \times 2 \mathrm{~m}$ positioned at the center of the trapping station in an east-west orientation; number of saplings in a transect of $6 \times 2 \mathrm{~m}$ positioned at the center of the trapping station in an east-west orientation; classes of abundance of bamboos in a $3 \mathrm{~m}$ radius $(0=$ absent, $1=$ few individuals and 2 = abundant); classes of abundance of ferns in a $3 \mathrm{~m}$ radius $(0=$ absent, 1 = few individuals and 2 = abundant $)$; sum of largest width of exposed rocks within a $3 \mathrm{~m}$ radius of the trapping station; sum of lengths of fallen logs with diameter $>10$ $\mathrm{cm}$ in a $3 \mathrm{~m}$ radius of the trapping station; weight of dry litter, collected at each trapping station in an area of $0.2 \mathrm{~m}^{2}$; and classes of land inclination $\left(0=0\right.$ to $5^{\circ}, 1=5$ to $30^{\circ}$ and $2=$ higher than $30^{\circ}$ ) measured at the trapping station. 


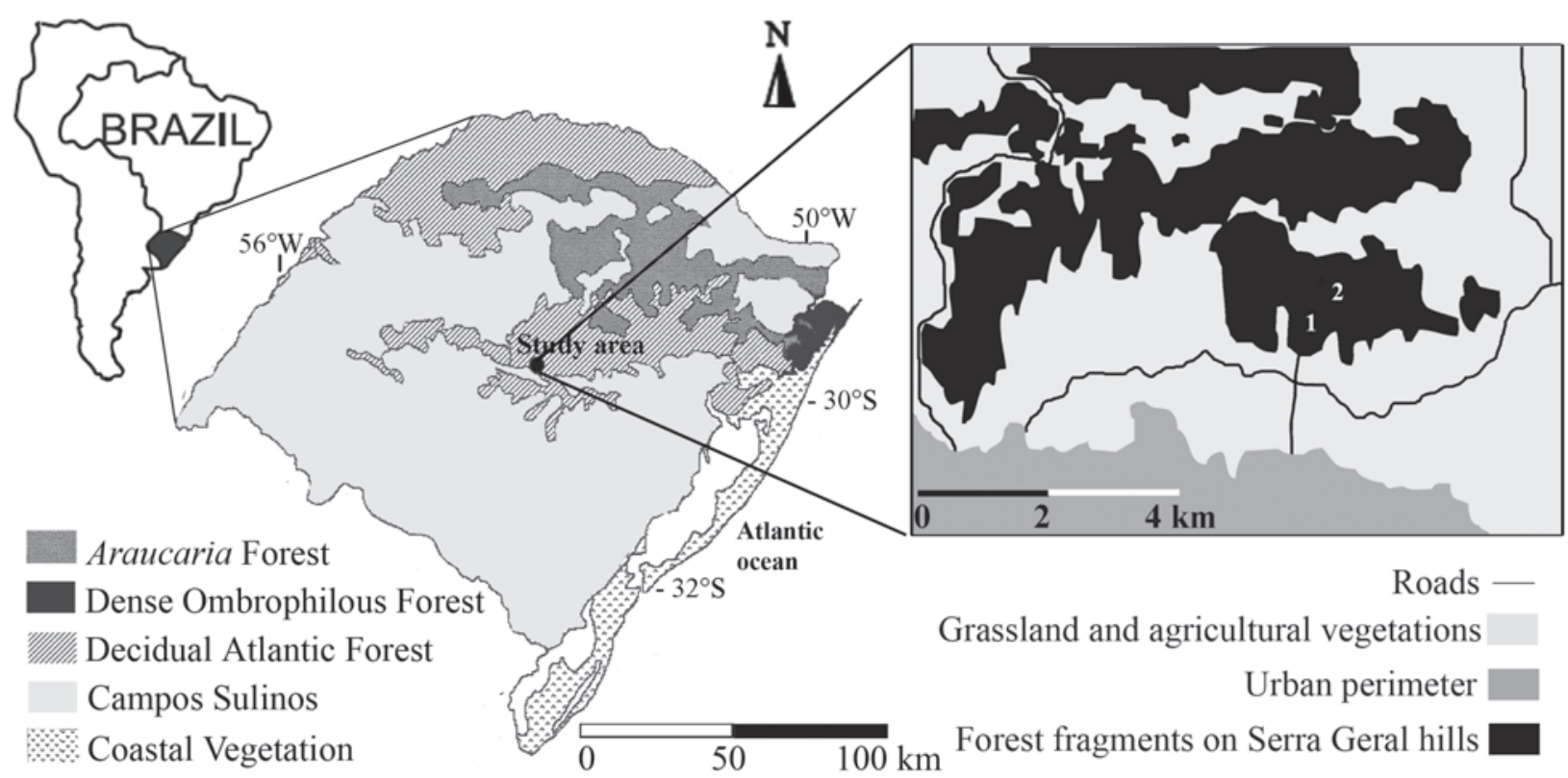

Figure 1. Location of study area in South America and in the state of Rio Grande do Sul, Brazil. The number 1 and 2 are references to the position of each trapping grid in the forest fragment studied, locally named Morro do Elefante.

We used the number of individuals captured for each species as a proxy of species abundance. The number of captures was also used to analyze microhabitat use by he three most frequent species (based on the first captures only, to ensure data independency). We used the number of captures of each rodent species in each trapping station instead of merely presence/absence. The correlation between animal captures in each trapping station with habitat measures in the same station was evaluated by principal component analysis (PCA), using the captures of rodents as a supplementary variable (VALENTin 2000).

PCA aims to optimally represent objects in a new space of uncorrelated axes which are linear combinations of a set of object measures. The scores of the measures in the factorial axes express their importance for each axis and similarity in these scores can be directly interpreted in terms of correlations between variables. Supplementary variables (e.g. rodent captures) can be also represented with the environmental variables in the ordination space. They do not participate in the computation of the PCA and enable the characterization of supplementary variables according to their locations with respect to the main variables in the analysis. Consequently, PCA enables the comparison of a reference population (microhabitat variables) with a tested one (rodent captures).

The PCA assumes linear relationships between all variables, an assumption that is not suitable for data with a large range of variation. However the environmental variations found in this study were low, making it possible to assume linearity between the number of captures and environmental variations.

\section{RESULTS}

As a result of a total effort of 3,920 trap-nights, 142 individuals of seven species were captured: six rodents and one species of marsupial (Tab. I), corresponding to a trapping success of $3.6 \%$. Trapping successes of pitfall and live traps were $4.05 \%$ and $3.26 \%$, respectively. One exotic species was captured, the house mouse Mus musculus (Linnaeus, 1758). Akodon montensis (Thomas, 1913) was the most frequent species in our samples, followed by Oligorizomys nigripes (Olfers, 1818) and Sooretamys angouya (Thomas, 1913). Thaptomys nigrita (Lichtenstein, 1829)

Table I. Small mammal species sampled and the number of captures in live traps and pitfall traps in the Morro do Elefante, municipality of Santa Maria, southern Brazil.

\begin{tabular}{lcc}
\hline \multicolumn{1}{c}{ Species } & Live trap & Pitfall \\
\hline Cricetidae & 55 & 36 \\
Akodon montensis & 6 & 21 \\
Oligoryzomys nigripes & 8 & 5 \\
Sooretamys angouya & - & 6 \\
Thaptomys nigrita & - & 1 \\
Juliomys sp. & 1 & 1 \\
Muridae & & \\
$\quad$ Mus musculus & 2 & - \\
Didelphidae & & \\
Didelphis albiventris &
\end{tabular}


is recorded in the state of Rio Grande do Sul for the first time in this study.

The first axis in the PCA ordination explained $20 \%$ of the data variance. Greater values in this axis are indicative of a forest in the mature stage, with a large number of trees, great canopy cover and abundance of litter. The amount of exposed rock was also correlated with higher values in the first axis. In the opposite direction there were land inclination and abundance of ferns. The second axis explained $14 \%$ of the data variance. Greater values for this second axis represent great abundance of saplings and scrubs and a high forest canopy. The other extremity of this axis represents abundance of bamboos and ferns. Akodon montensis was correlated only with the second axis, mainly associated with the abundance of bamboos. Oligoryzomys nigripes was also correlated with the second axis, however in the opposite direction, positively correlated with the number of scrubs. Regarding the first axis, $O$. nigripes was negatively correlated with the mature forest indicators. Sooretamys angouya had similar scores on PCA axes to A. montensis, being negatively correlated with the second axis. However, $S$. angouya had a weaker correlation with the both axes and was positioned closer to the center of the ordination space (Fig. 2).

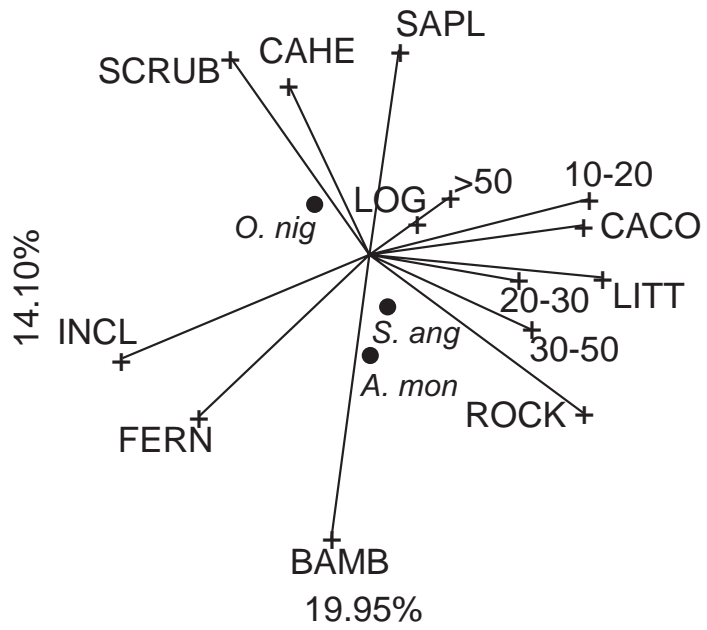

Figure 2. Principal component analysis of microhabitat variables (active variables, represented by crosses) and abundances of the three most common rodents (supplementary variables, represented by filled circles).Variable abbreviations: (10-20) number of trees between 10 and $20 \mathrm{~cm}$ of perimeter at breast height (PBH); (2030) number of trees between 20 and $30 \mathrm{~cm}$ of $\mathrm{PBH}$; (30-50) number of trees between 30 and $50 \mathrm{~cm}$ of $\mathrm{PBH} ;(>50)$ number of trees larger than $50 \mathrm{~cm}$ of $\mathrm{PBH}$; (CACO) canopy cover above trapping station; (CAHE) canopy height above trapping station; (LOG) fallen logs; (BAMB) abundance of bamboos; (FERN) abundance of ferns; (SAPL) number of saplings; (SCRU) number of scrubs; (INCL) land inclination;(LITT) dry litter; (ROCK) exposed rocks. For rodents: (A. mon) A. montensis; (O. nig) O. nigripes; and (S. ang) S. angouya.

\section{DISCUSSION}

The small mammal's species richness found in this study can be considered low for the Atlantic Forest, especially when compared with similar studies carried out in the central, northern portion of the biome (BERgallo 1994, Bonvicino et al. 2002, PARDINI \& UMETSU 2006). Our results, however, are consistent with findings for other small mammal communities in the Araucaria Forest (CAdemartori et al. 2004, Dalmagro \& Vieira 2005) and in the Dense Ombrophilous Forest of southern Brazil (CÁCEREs 2004, CHEREM 2005), where four to 10 species have been recorded. A higher number of species (18 species) was reported by Scheibler \& Christoff (2007) for an area of the austral Deciduous Atlantic Forest. However, since their study included a wider diversity of habitats (including cultivated and uncultivated agricultural fields), their overall results cannot be compared with surveys carried out on forest habitats alone. In forest fragments, however, the authors found only four species, a result consistent with our findings. A comparison of similar species inventories carried out in the Atlantic Forest reveals that small mammal's richness decreases along the latitudinal gradient, a pattern that has been reported for many different taxa (Stevens 1989, Kaufman \& Willig 1998, Willig \& Lyons 1998, Willig et al. 2003, Hillebrand 2004).

The native rodents with small number of captures in our data are endemic to the Atlantic Forest: $S$. angouya, T. nigrita and Juliomys sp. The first species occurs in the central (Bonvicino et al. 2002, Geise et al. 2004, Umetsu et al. 2006) and austral portions of the Atlantic Forest (CÁceres 2004, CADEMARTORI et al. 2004, SCHEIBLER \& CHRISTOFF 2007). Thaptomys nigrita was recorded a few times in the central Atlantic Forest (Bonvicino et al. 2002, Geise et al. 2004, Pardini 2004, Umetsu et al. 2006) and in the austral Atlantic Forest (CÁCERES 2004). By contrast, rodents with the greater number of captures in our study area, A. montensis and $O$. nigripes, occur in several biomes. Both are common species in the central and austral Atlantic Forest (Bonvicino et al. 2002, Geise et al. 2004, Dalmagro \& Vieira 2005, Pardini \& UMetsu 2006) and in the Cerrado biome (Lyra-Jorge \& Pivello 2001). Oligoryzomys nigripes also occurs in the Pampas biome (Твотт et al. 2007). Our results on number of captures corroborate the hypothesis that a positive relationship exists between species abundance and distribution range. According to this hypothesis, within a taxonomic group, locally abundant species tend to have wide ranges, whereas locally rare species tend to have restricted distribution (BROwn 1984, GASTON 1996, JOHNSON 1998).

The relative abundance of each species expressed by the number of captures in our data is in agreement with the abundance patterns found for the same species in the central portions of the Atlantic Forest and in the Araucaria Forest. Bonvicino et al. (2002), studying areas of the central Atlantic Forest, considered $A$. montensis and $O$. nigripes as common and abundant; $S$. angouya as common but not abundant, and T. nigrita as both rare and not abundant. The first two species were also the most 
captured species in the Araucaria Forest (CADEMARTORI et al. 2004, Dalmagro \& Vieira 2005). In a Deciduous Forest area, Scheibler \& Christoff (2007) also found a similar pattern, with O. nigripes being the most frequent species in captures, while $S$. angouya was particularly rare. In that study, $A$. montensis was not recorded, but a congeneric species, $A$. paranaensis, was the most captured. The scarcity of Juliomys sp.in our sampling may be due to the fact that all species of the genus are apparently rare in small mammal communities (CosTA et al. 2007, PARDIÑAS et al. 2008). However, it is important to emphasize that sampling with small buckets and the sampling only on the ground can underestimate the abundance of certain species. Larger and/or the scansorial species may be able to jump from the bucket floor, and trapping on the ground level using standard live traps may limit the captures of scansorial species.

This study supplies the first record of Thaptomys nigrita in the state of Rio Grande do Sul, broadening the distributional range of this species to $650 \mathrm{~km}$ southwest of its previous record (CÁCeres 2004). It also provides the second record of Juliomys (González, 2000) (first recorded in Rio Grande do Sul by PAREsQue et al. 2009) in the state. Unfortunately, it was not possible to identify the Juliomys specimen captured by us beyond genus. It is possible that it represents a new species, as suggested by PARESQUe et al. (2009) for three individuals captured at Aparados da Serra National Park, Rio Grande do Sul. To our knowledge, our records represent the southernmost know distribution points for Juliomys sp. and also for T. nigrita. These findings may be a function of the trapping methods we have used. These two rodents were present only in pitfall traps, which have been increasingly acknowledged as an efficient trapping method (Williams \& Braun 1983, Lyra-Jorge \& Pivello 2001, Umetsu et al. 2006) that has been rarely used in southern Brazil. Our results highlight the importance of using pitfall traps in small mammal surveys, even if small buckets are used.

Oligoryzomys nigripes and $D$. albiventris are the only species captured in our study that are known from the Pampa biome (Cerqueira 1985, CÁceres et al. 2007, Trott et al. 2007), which is further south of our sampling area. All the others small mammal species recorded here are probably near to their austral distribution limits. However, we need to be weary of drawing conclusions until we have extensive surveys in the boundaries between Pampa and Atlantic Forest.

The number of captures of A. montensis was positively correlated with the abundance of bamboo. In the Araucaria Forest, Dalmagro \& Vieira (2005) had found a relationship between the abundance of this species and higher percentages of canopy cover. Since both abundance of bamboo and canopy cover tend to decrease the probability that a predator will see a small rodent, the positive association between $A$. montensis and these two parameters may be a function of predator avoidance. In Chilean temperate forests, Akodon olivaceus (Waterhouse, 1835) (Cricetidae) was found to be more abundant when canopy cover was dense (Múrua \& González 1982), and in the central
Atlantic Forest, A. cursor (Winge, 1887) (Cricetidae) was found more often in places with high herbaceous density near to the ground and high litter density (Gentile \& Fernandez 1999). Similar results were found for other terrestrial species of rodents in different regions (Vieira et al. 2005, Corbalán et al. 2006). These studies suggest that escape from predation is an important aspect of microhabitat selection by small mammals, particularly the most terrestrial ones.

Oligoryzomys nigripes used places with high abundance of scrubs. Considering its scansorial behavior (VIEIRA \& MonTeIROFILHO 2003), it would be expected that this rodent favors places with dense understory cover, which is provided mainly by scrubs in the study area. Likewise, this species was positively correlated with vegetation density at $1 \mathrm{~m}$ above ground in the Araucaria Forest (DALmagro \& Vieira 2005) and places with dense understory in secondary Atlantic Forest remnants in southeastern Brazil (PÜTTKER et al. 2008). In the same way, the scansorial rodent Oligoryzomys longicaudatus (Bennett, 1832) (Cricetidae), was found to favor high foliage density provided by dense understory in Chilean temperate forests (Múrua \& GonZÁLEZ 1982). Another important issue is that $O$. nigripes was negatively correlated with variables that were indicators of a mature forest. This result corroborates PÜTTKER et al. (2008), who found this species occurring mainly at locations with vegetation characteristic of a disturbed forest. PÜTTKER et al. (2008) suggested that microhabitat preferences may be an important factor influencing the capacity of small mammals to occupy altered habitats.

Sooretamys angouya, in our data, had PCA scores very close to A. montensis, mainly in relation to bamboos. This is an indication that these two species use similar microhabitats. Since microhabitat does not seem to be a niche dimension in which these two species segregate, it seems reasonable to assume that there are other dimensions of niche segregation between these two species, such as diet and use of the forest strata. Species of Akodon are omnivorous-insetivorous (FonseCA et al. 1996, CAMpos et al. 2001, Giannoni et al. 2005, CASElla \& Cáceres 2006) while the rodents of "Oryzomys" group are omnivorous-granivorous (Fonseca et al. 1996, EMmONs \& FeEr 1997). The two rodents also differ in the use of the vertical forest strata: species of Akodon are strictly terrestrial (Emmons \& Feer 1997, Vieira \& Monteiro-Filho 2003), whereas $S$. angouya is mainly scansorial (CAdemartori et al. 2002). The small overlap in their diet and in their use of different vertical strata allows a larger overlap in microhabitat use without competitive exclusion.

In summary, relatively poor small mammal richness, when compared with the southeastern Dense Ombrophilous Forest, was documented for the area of the austral Deciduous Forest surveyed in this study. This result is consistent with data obtained for other austral communities in the Araucaria Forest and the Dense Ombrophilous Forest. All species recorded in our study also occur in regions of the Atlantic Forest north of the area surveyed. The most common species in our study, $A$. montensis and $O$. nigripes, were also the most common or abun- 
dant in the majority of faunistic surveys of the Atlantic Forest, and have a wider geographical range. Captures of $A$. montensis and $S$. angouya were correlated with places having an abundance of bamboo. Conversely, O. nigripes used areas with high density of scrubs. The two most abundant species used very different microhabitats, highlighting the importance of microhabitat use in this community. However, considering the relationship between $A$. montensis and S. angouya the microhabitat use does not seem to be the only factor responsible for the structure of this small mammal community.

\section{ACKNOWLEDGEMENTS}

We are indebted to our friends from the Laboratório de Ecologia de Mamíferos e Aves at UFSM for helping with fieldwork and for many useful discussions, especially Jeferson S. Arruda and Marcelo M. Weber. Alexandre U. Christoff, João A. de Oliveira and Pedro Estrela helped with the rodent identifications. Eduardo H. Giehl and Jean L. Valentin gave essential suggestions in the statistical analyses. Diogo Loretto, Jayme A. Prevedello, Pamela C. Antunes, Sandra M. Hartz and two anonymous referees provided constructive criticism which was essential to improving the manuscript. Personal grants were given by PET/SESu/MEC - Programa de Educação Tutorial for the first two authors and by Fundo de Amparo à Pesquisa do Rio Grande do Sul for VLC. NCC is CNPq's research fellow. IBAMA authorized the fieldwork under process number 021/05.

\section{LITERATURE CITED}

Antunes, P.C; M.A.A. Campos; L.G.R. Oliveira-Santosa \& M.E. GraiPel. 2009. Population dynamics of Euryoryzomys russatus and Oligoryzomys nigripes (Rodentia, Cricetidae) in an Atlantic forest area, Santa Catarina Island, Southern Brazil. Biotemas 22 (2): 143-151.

Bergallo, H. 1994. Ecology of small mammal community in an Atlantic Forest area in Southeastern Brazil. Studies on Neotropical Fauna and Environment 29 (4): 197-217.

Bonvicino, C.R.; S.M. Lindbergh \& L.S. Maroja. 2002. Small nonflying mammal from conserved and altered areas of Atlantic Forest and Cerrado: comments on their potential use for monitoring environment. Brazilian Journal of Biology 62 (4): $1-12$.

Brannon, M.P. 2000. Niche relationships of two syntopic species of shrews, Sorex fumeus and S. cinereus, in the southern Appalachian Mountains. Journal of Mammalogy 81 (4): 1053-1061.

Brown, J.H. 1984. On the Relationship between Abundance and Distribution of Species. The American Naturalist 124 (2): 255-279.

CÁCeres, N.C. 2004. Occurrence of Conepatus chinga (Molina) (Mammalia, Carnivora, Mustelidae) and other terrestrial mammals in the Serra do Mar, Paraná, Brazil. Revista Brasileira de Zoologia 21 (3): 577-579.
Cáceres, N.C.; J.J. Cherem \& M.E. Graipel. 2007. Distribuição geográfica de mamíferos terrestres na Região Sul do Brasil. Ciência \& Ambiente 35: 167-180.

Cademartori,C.V.; R.V. Marques; S.M. Pacheco; L.R.M. Baptista \& M. GARCIA. 2002. Roedores ocorrentes em floresta ombrófila mista (São Francisco de Paula, Rio Grande do Sul) e a caracterização de seu habitat. Comunicações do Museu de Ciências e Tecnologia, PUCRS, Série Zoologia, 15 (1): 61-86.

Cademartori, C.V.; M.E.Fabí́n \& J.O.Menegheti. 2004. Variações na abundância de roedores (Rodentia, sigmodontinae) em duas áreas de floresta ombrófila mista, Rio Grande do Sul, Brasil. Revista Brasileira de Zoociências 6 (2): 147-167.

Campos, C.; R. OJeda; S. Monge \& M. Dacar. 2001. Utilization of food resources by small and medium-sized mammals in the Monte Desert biome, Argentina. Austral Ecology 26 (2): 142-149.

Casella, J. \& N.C. Cáceres. 2006. Diet of four small mammal species from Atlantic Forest patches in South Brazil. Neotropical Biology and Conservation 1 (1): 5-11.

Cerqueira, R. 1985. The distribution of Didelphis in South America (Polyprotodontia, Didelphidae). Journal of Biogeography 12: 135-145.

Cherem, J.J. 2005. Registros de mamíferos não voadores em estudos de avaliação ambiental no sul do Brasil. Biotemas 18 (2): 169-202.

Collins, M. 1990. The last rain forests. London, Mitchell Beazley Publication/IUCN, 200p.

Corbalán, V.; S. Tabeni \& R.A. Ojeda. 2006. Assessment of habitat quality for four small mammal species of the Desert, Argentina. Mammalian Biology 71 (4): 227-237.

Costa, L.P.; S.E. Pavan; Y.L.R. Leite \& V. Fagundes. 2007. A new species of Juliomys (Mammalia: Rodentia: Cricetidae) from the Atlantic Forest of southeastern Brazil. Zootaxa 1463: 21-37.

Dalmagro, A.D. \& E.M. Vieira. 2005. Patterns of habitat utilization of small rodents in an area of Araucaria Forest in Southern Brazil. Austral Ecology 30: 353-362.

Dueser, R.D. \& H.H. Shugart JR. 1978. Microhabitats in a forestfloor small mammal fauna. Ecology 59 (1): 89-98.

EMmons, L.H. \& F. FeER. 1997. Neotropical rainforest mammals: a field guide (Second edition). Chicago, The University of Chicago Press, XVI+307p.

Fa, J.E.; F.J. Romero \& J. Lopez-Paniagua. 1992. Habitat use by parapatric rabbits in a mexican high-altitude grassland system. Journal of Applied Ecology 29 (2): 357-370.

Fonseca, G.A.B.; G. Hermmann; Y.L.R. Leite; R.A. Mittermeier; A.B. Rylands \& J.L. Patton. 1996. Lista anotada dos mamíferos do Brasil. Occasional Papers in Conservation Biology 4: 1-38.

Gaston, K.J. 1996. The multiple forms of the interspecific abundance-distribution relationship. Oikos 76 (2): 211-220.

Geise, L.; L.G. Pereira; D.E.P. Bossi \& H.G. Bergallo. 2004. Pattern of elevational distribution and richness of non volant mammals in Itatiaia National Park and its surroundings, in 
southeastern Brazil. Brazilian Journal of Biology 64 (3B): 599-612.

Gentile, R. \& F.A.S. Fernandez. 1999. Influence of habitat structure on a streamside small mammal community in a Brazilian rural area. Mammalia 63 (1): 29-40.

Giannoni, S.M.; C.E. Borghi; M. Dacar \& C.M. Campos. 2005. Main food categories in diets of sigmodontine rodents in the Monte (Argentina). Mastozoología Neotropical 12 (2): 181-187.

Graipel, M.E; J.J. Cherem; E.L.A. Monteiro-Filho \& L. Glock. 2006. Dinâmica populacional de marsupiais e roedores no Parque Municipal da Lagoa do Peri, ilha de Santa Catarina, sul do Brasil. Mastozoologia Neotropical 13 (1): 31-49.

Hillebrand, H. 2004. On the generality of the latitudinal diversity gradient. The American Naturalist 163 (2): 192-211.

Johnson, C.N. 1998. Species extinction and the relationship between distribution and abundance. Nature 394 (6690): 272-274.

KaUfMan, D.M. \& M.R. Willig. 1998. Latitudinal patterns of mammalian species richness in the new world: the effects of sampling method and faunal group. Journal of Biogeography 25 (4): 795-805.

Lyra-Jorge, M.C. \& V.R. Pivello. 2001. Combining live trap and pitfall to survey terrestrial small mammals in savanna and forest habitats, in Brazil. Mammalia 65 (4): 524-530.

Machado, P.F.S. \& S.J. Longhi. 1989. Aspectos florísticos e fitossociológicos do 'Morro do Elefante', Santa Maria, RS. Revista Centro de Ciências Rurais 20 (3-4): 261-280.

Moreno, J.A. 1961. Clima do Rio Grande do Sul. Porto Alegre, Secretaria da Agricultura, Divisão de Terras e Colonização, 42p.

MúruA, R. \& L.A. GonZÁlez. 1982. Microhabitat selection in two chilean cricetid rodents. Oecologia 52: 12-15.

Myers, N.; R.A. Mittermeier; C.G. Mittermeier; G.A.B. Fonseca \& J. Kent. 2000. Biodiversity hotspots for conservation priorities. Nature 403 (24): 853-858.

Pardiñas, U.F.J.; P. Teta; G. D’elía \& C. Galliari. 2008. Rediscovery of Juliomys pictipes (Rodentia: Cricetidae) in Argentina: emended diagnosis, geographic distribution, and insights on genetic structure. Zootaxa 1758: 29-44.

PARdini, R. 2004. Effects of forest fragmentation on small mammals in an Atlantic Forest landscape. Biodiversity and Conservation 13: 2567-2586.

Pardini, R. \& F. Umetsu. 2006. Pequenos mamíferos não-voadores da Reserva Florestal do Morro Grande - distribuição das espécies e da diversidade em uma área de Mata Atlântica. Biota Neotropica 6 (2).

Paresque, R; A.U. Christoff \& V. Fagundes. 2009. Karyology of the Atlantic forest rodent Juliomys (Cricetidae): A new karyotype from southern Brazil. Genetics and Molecular Biology 32 (2): 301-305.
PÜtTKer, T.; R. PARdini; Y. Meyer-Lucht \& S. SOmmer. 2008. Responses of five small mammal species to micro-scale variations in vegetation structure in secondary Atlantic Forest remnants, Brazil. BioMed Central Ecology 8: (9).

Quadros, F.L.F. \& V.P. Pillar. 2002. Transições floresta-campo no Rio Grande do Sul. Ciência e Ambiente 24: 109-118.

Scheibler, D.R. \& A.U. Christoff. 2007. Habitat associations of small mammals in southern Brazil and use of regurgitated pellets of birds of prey for inventorying a local fauna. Brazilian Journal of Biology 67 (4): 619-625.

Schoener, T.W. 1974. Resource partitioning in ecological communities. Science 185: 27-39.

Seagle, S.W. 1985. Competition and Coexistence of Small Mammals in an East Tennessee Pine Plantation. American Midland Naturalist 114 (2): 272-282.

Stevens, G.C. 1989. The Latitudinal Gradient in Geographical Range: How so Many Species Coexist in the Tropics. The American Naturalist 133 (2): 240-256.

Trott, A.; S.M. Callegari-Jacques; L.F.B. Oliveira; A. Langguth \& M.S. Mattevi. 2007. Genetic diversity and relatedness within and between species of the genus Oligoryzomys (Rodentia; Sigmodontinae). Brazilian Journal of Biology 67 (1): 153160 .

Umetsu, F.; L. Naxara \& R. Pardini. 2006. Evaluating the efficiency of pitfall traps for sampling small mammals in the neotropics. Journal of Mammalogy 87 (4): 757-765.

VALENTIN, J.L. 2000. Ecologia Numérica: uma introdução à análise multivariada de dados ecológicos. Rio de Janeiro, Interciência, 114p.

Vieira, E.M. \& E.L.A. Monteiro-Filho. 2003. Vertical stratification of small mammals in the Atlantic rain forest of south-eastern Brazil. Journal of Tropical Ecology 19: 501-507.

Vieira, E.M.; G. Iob; D.C. Briani \& A.R.T. Palma. 2005. Microhabitat selection and daily movements of two rodents (Necromys lasiurus and Oryzomys scotti) in Brazilian Cerrado, as revealed by a spool-and-line device. Mammalian Biology 70 (6): 359-365.

Williams, D.F. \& S.E. Braun. 1983. Comparison of pitfall and conventional traps for sampling small mammal populations. Journal of Wildlife Manage 47 (3): 841-845.

WILLIG, M.R. \& S.K. Lyons. 1998. An analytical model of latitudinal gradients of species richness with an empirical test for marsupials and bats in the New World. Oikos 81: 93-98.

Willig, M.R.; D.M. Kaufman \& R.D. Stevens. 2003. Latitudinal gradients of biodiversity: pattern, process, scale, and synthesis. Annual Reviews in Ecology, Evolution, and Systematics 34: 273-309.

YAHNER, R.H. 1982. Microhabitat use by small mammals in farmstead shelterbelts. Journal of Mammalogy 63 (3): 440-445.

Submitted: 24.I.2009; Accepted: 16.I.2010.

Editorial responsibility: Paulo Inácio López de Prado 